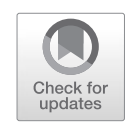

\title{
Conclusions: The Neo-Nationalist Order
}

In the last half century, nativist populist political parties have over three waves moved from the fringe to the mainstream in European and American politics. This has led to a new kind of nationalism thriving, distinct from that of previous eras-emerging into a separate Neo-Nationalism in the post-war era.

The first contemporary nativist populist parties to find significant success emerged in Western Europe in the early 1970s, such as in France, Denmark and Norway. However, earlier populists had already found initial support in the Alpine countries, and an agrarian-populist party was established in Finland in 1959. Far-right populism travelled east in the 2000s, when a promise of prosperity accompanying new-found liberal democracy was failing to materialize in many places. In the wake of the Financial Crisis of 2008, populism snowballed south, often taking a more leftist form. On the canopy of the Refugee Crisis in the wake of the Syrian War, anti-immigrant and far-right populism found foothold even in Germany, where such sentiments had been suppressed after the devastations of Nazism. Whether the Coronavirus Crisis of 2020 will lead to another rise of Neo-Nationalism remains to be seen.

Since the 2014 European Parliament election, Neo-Nationalists have come to dictate much of the political agenda in the West. The year 2016 brought a double shock with the Brexit vote in the UK and the election of Donald Trump to the White House in the US. In 2017 Marine Le Pen easily graduated to the run-off in the presidential elections in France, winning one-third of the vote. In 2018, two populist parties united in a

(C) The Author(s) 2020 209

E. Bergmann, Neo-Nationalism, https://doi.org/10.1007/978-3-030-41773-4_6 
government coalition in Italy. And in the 2019 European Parliament election, populist parties again won a record number of seats.

These parties have progressed in varying ways in the different areas in Europe and in America, and they have taken different forms from north to south. For instance, they have evolved very differently in the former communist countries in Eastern Europe from those in the old Western Europe. Many of the leaders here discussed, the Le Pens, Victor Orbán, Vladimir Putin, Geert Wilders, Jörg Haider and Matteo Salvini were fully far-right nativist populists. Some were rooted in other ideologies and only flirted with these traits, such as Silvio Berlusconi, Beppe Grillo and Donald Trump. The same can be said about Perón in Argentina.

The Neo-Nationalist order of our time culminated when three torrents coincided at a common confluence, fusing into a single channel of much greater velocity: the surge of populist politics, the spread of conspiracy theories and the avalanche of misinformation boosted by changes in the media. As I have illustrated in this book, nativist populist leaders were in the the new digital media environment able to spread conspiracy theories and misinformation much further than before, crafting an especially successful recipe for undermining the political establishment.

In this new media environment, the populists were able to bypass the former gatekeepers of the mainstream media and take their appeal directly to the people. By playing on controversies the populist attracts attention. The scandalous message prompts pushback from the establishment, which the populist can then use to spread his agenda even further. As I discussed in the previous chapter, the mainstream media can then easily be baited to pick up the bogus tale, distributing it much further than was possible on social media alone.

As I have documented throughout in this book, the surge of nativist populism has risen directly in opposition to migration, especially in the third wave. The most powerful conspiracy theory fuelling the extremist versions of nativist populism is that of the Great Replacement. In its essence this is the claim that immigrants were flocking to predominantly white Christian countries for the precise purpose of rendering the native population a minority within their own land, or even causing their extinction.

Fear of subversion is only the first part of the full theory. In its complete form the domestic elite is simultaneously accused of betraying the good ordinary people into the hands of the external evil. The full version of the Great Replacement conspiracy theory is more commonly upheld on the 
fringes. However, many prominent contemporary nativist populists have also alluded to it. Often times, they would rather hint to it, in a style of dog-whistling, than fully spelling it out.

Europe is a continent of inhered tensions. It has for long been torn between ideas of openness and liberal democracy on the one hand and xenophobia and authoritarian nationalism on the other. For comprehending its political culture, it is important to understand that it is a product of both trends.

After the devastations of the two world wars, nationalism was not only discredited but also widely and firmly held in contempt. Nationalism was equated with racism. However, after having been completely contemned for most of the post-war era, another form of racism was-over the progression of the three waves of nativist populism identified in this book-becoming a new normal in Europe and in America. The new racism was not based on biology as in previous eras, but rather on culture. This is a culturally based ethno-pluralist doctrine of 'equal but separate' where biological racism was replaced with cultural xenophobia.

Vitally for the story told on these pages, descendants of well-integrated migrants with an established history in society are thus not necessarily excluded from the domestic demos. Instead they become part of 'us' against 'other' external migrants.

Although the contemporary nativist populism is fundamentally different to the fascism of former times, many of the populist movements still do tap into similar notions of nationalism, ethno-centrism and ideas of cultural separatism. Like the fascists before, contemporary nativist populists also uphold a Manichean worldview when incessantly dividing between good and evil. In doing so they tend to position themselves as outsiders fighting alongside the common man against the malignant elite.

The success of the contemporary nativist populists was indeed based on dressing their scandalous message in more benign clothing than the fascists. This is the process of normalizing previously condemned views, such as racism, by way of coded rather than explicit xenophobia.

Although most nativist populists were primarily focused on conditions within their own native societies, they also tended to strike similar tones. A common theme was to offer a contract with the people, for the benefit of the masses against the elite. In Italy, Silvio Berlusconi offered a contract with Italians. Jörg Haider similarly offered a contract with Austrians, and before the 2019 general election in the UK, Nigel Farage of the Brexit Party tendered a contract with the British public. 
Another trope was in putting 'our' people first. The FPÖ in Austria published a programme called 'Austria First', stating that Austria would not become an immigrant country. This is similar to Donald Trump in America who campaigned on the notion of 'America First'. That slogan had often been heard before. In the interwar years, the public face of the America First Movement was aviation legend and Nazi sympathizer, Charles Lindbergh. In Italy Matteo Salvini similarly ran on a slogan of 'Italians First'.

Taking back control was also a common theme of nativist populists, for instance upheld in the Brexit debate in the UK. In America Donald Trump ran on a similar chant: 'Make America Great Again'-a slogan that had previously been used by Ronald Reagan.

Definitions of nationalism and populism are fleeting in the literature, and the specifically nativist populism has been somewhat overlooked. In this book I have attempted to illustrate how populist movements have become increasingly ethno-nationalist, and, indeed, nativist. Their nativism has mainly been sharpened in opposing 'others' in society, primarily in protecting the native population against an influx of immigrants. This is the politics of separating outgroups from 'the people'.

In this book I have identified several common features of post-war nativist populism. These are nationalist parties, nativist and exclusionary, that campaign against multiculturalism and strive to stem flow of immigration. Usually they revolve around a strong charismatic leader. Most often they are anti-intellectual and anti-elitist. Another aspect is their simplicity, often insisting on simple and straightforward solutions to meet complex national interest. Often they are moralistic rather than practical, and they tend to be protectionist of national production from international competition. Also, populist parties are usually authoritarian and social conservatives, they belief in a strictly ordered society and are much rather defined on socio-cultural aspects than on the socio-economic scale. Finally, populists in Europe are most often staunchly Eurosceptic.

As I laid out in the book's second chapter, definitions of specifically nativist populists are here framed through identifying a threefold claim for their support of the people. First, nativist populists tend discursively to create an external threat to the nation. Secondly, they accuse the domestic elite of betraying the people, often even of siding with the external forces. Thirdly, they position themselves as the only true defenders of the pure people they vow to protect against these malignant outsiders. 
One of the features separating nativist populists from the fascists of previous times is that they do not necessarily denounce democracy, at least not in name. They are however in opposition to the liberal side of the post-war liberal democratic order.

In addition to increased systemic cross-border state co-operation and pooling of sovereignty, the post-war liberal democratic system rested on shared values, including the rule of law, firm division of power, free trade across borders, respect for human rights, wide reaching civil rights, unbiased and professional administration, and a free and independent media. This was the liberal aspect of the post-war democratic order installed to protect individuals and minorities from oppression by the majority. These basic rules of liberal democracies were respected across the political spectrum and the system indeed celebrated human diversity. It actively and persistently countered collectiveness.

With the collapse of communism many people predicted that this kind of liberal democracy would prevail for the foreseeable future. However, as here has been explored, the picture was not to be so simple. In fact, nativist populists have surged, sometimes precisely due to their disrespect for this shared framework of liberal democracy. It is indeed via their willingness in disposing of these shared democratic values that much of their appeal comes from.

When thinking of fascists coming to power, we can commonly envision violent coups d'état, such as in Argentina, Chile, Greece, Thailand and Turkey. However, fascists also emerged through traditional democratic routes. As I discussed in the Introduction to this book, the interwar fascist regimes in both Italy and in Germany, however, came about via mechanisms of parliamentary democracy. Both were elected, and both had to rely on mainstream collaborators to form a government. Only in co-operation with mainstream political partners were Mussolini and Hitler able to reign in Rome and in Berlin. And it was only from that democratic position that they were subsequently able to abandon democratic elections. In other words, democracy was in these cases destroyed from within.

Similar to nationalists more generally, the relationship populists have with democracy can also be quite murky, and, thus, sometimes difficult to predict. Populist leaders often start out as being democratic, or at least pretend to be. They would often champion the use of direct democracy, however commonly in a highly selective way, fitted to their own agenda. Many of them even portrayed themselves as particular protectors of democracy, only revealing their true authoritarian tendencies after 
resuming power. This was for instance true in Venezuela. Hugo Chávez was democratically elected to office. Only after being elevated to power by way of democratic processes, was he-and later his successor, Nicolás Maduro-able to dismantle the very democratic processes that had brought them to power. As has here been explored, similar processes have been evident in Russia under Vladimir Putin and in Hungary under Victor Orbán. Into this mix, we can also append Perón in Argentina and Fujimori in Peru.

Nativist populists do not usually oppose elections. But some of them have proved prone to controlling their outcomes. When seeing oneself as the interpreter of the will of the people, a populist leader in power might not find it too problematic to diverge from conventional democratic practices rather than always allowing his mainstream opponents-those that he deems being traitors of the people - to compete on a level playing field. Instead, he might offer a rationale for it being more democratic to ensure the will of the people, as interpreted by the populist himself.

Rather than rejecting democracy as such, some nativist populists have instead introduced an illiberal form of democracy, dismissing diversity and removing the emphasis on individual rights and separation of power. Instead of liberal democracy, this is democracy without liberal rights.

The relevant question here is thus not only whether populists denounce democracy in name, but rather whether they respect it in reality.

As already discussed, authoritarian leaders have eroded democracy both via coups d'état, and by abandoning democracy after being democratically elected. More often than not, democracies die rather more gradually, often without us even noticing their demise. Democracy is thus much rather circumvented than abolished-gradually being eroded via incremental implementation of slowly evolving authoritarian rule.

History holds many examples when polarization has gone so far that mainstream actors have been tempted to collaborate with the demagogues, rather than reach across the traditional dividing lines in domestic politics. In doing so, there are instances where mainstream actors have unwittingly facilitated the demise of democracy and paved the way for populists coming to power.

Given the right conditions, all democracies can abandon their principles and turn to autocracy. In fact, history tells us this might easily happen. However, history also tells us, as is discussed above, that when the 
mainstream establishment is able to unite against illiberal forces then they are usually in a position to stem their surge. Populists rarely muster the support of the majority. Thus they often need help from the mainstream to gain control.

Conventional wisdom states that populist political movements do not last, that they have inbuilt difficulties of persistence. The resilience of many of the parties examined here has however proved those predictions to be wrong. Rather, much of their political message has prevailed over many decades. In several cases, as documented here, they have been able to find legitimacy and pull the national discourse in their own direction.

Although populism has been elevated on waves of crises, there are also many examples where such parties have persisted far passed any economic difficulties and have found support even in times of recovery after crisis and relative economic prosperity.

In recent years populism has indeed been immersed into mainstream politics. Contemporary Europe-wide opinion polls have shown that twothirds of the population think that their country has reached its limit in accepting migrants. Anti-immigrant and authoritarian sentiments are thus not isolated on the fringes of society, they are no longer alien from the ordinary population.

This process of the normalization of populist politics occurs, for example, when mainstream parties follow suit in the wake of the populists, and in their quest for winning back lost supporters start themselves to abandon the once-shared values of Western liberal democracies. On that route, the Cordon Sanitaire that the mainstream had in many places encircled around the rough nativist populists was gradually loosening. This is the process of eroding once-shared democratic norms. Progression of this kind has, for example, occurred in Austria, Denmark and in the Netherlands.

In the UK, the Conservative Party was able to suppress first UKIP and then the Brexit Party by more or less adopting their approach on Brexit. This is similar to the move made by Mark Rutte in the Netherlands, and that of the Social Democrats in Denmark.

Denmark is a curious example of this trend. For over almost two decades the nativist populist Danish Peoples Party was continuously finding ever greater authority. By the 2019 general election they had however fallen victim to their own success, after other parties had more or less adopted their policies. This is particularly interesting as it illustrates how 
the demise of a populist party does not necessarily mean the rejection of its politics. In some instances, like in Denmark, it indeed rather indicates its ultimate success - in making the mainstream following it, and permanently altering existing policies.

Nativist populism has evolved over the past years and decades. When Herbert Kitschelt introduced what he called the 'winning formula' of right-wing populism in the late 1990s, he argued that its success came primarily in combining neo-liberal politics with authoritarianism and a policy of anti-immigration. As I have illustrated on these pages, another aspect has, however, become increasingly important for populist politicians. That is in speaking on behalf of the ordinary man against a corrupt elite while in an aggressive style pointing to an imminent external threat. The winning formula of contemporary nativist populists is thus also found in the dual process of instating fear and scapegoating. First fear is created and then blame is attributed. The fear is used to legitimize their means of protecting the people, of putting up barriers, closing borders, ousting immigrants, exiting international institution, emasculating the elite, and so on.

The relationship between populism and liberalism is precarious. Most obviously, these are usually quite authoritarian actors, emphasizing Christian family values and strongman leadership. However, with increased emphasis on opposing Islamization in the West many of these parties have shifted to position themselves as the protectors of Western liberalism, mainly when it comes to gay rights and gender equality.

Pim Fortuyn in the Netherlands was a pioneer in this regard, positioning himself as an ally of the LGBTQ community. Some of the Scandinavian populist parties have also somewhat followed suit, such as the Danish Peoples Party, the Norwegian Progress Party-both were under female leadership - and the Sweden Democrats. In these instances, the nativist populism was not necessarily anti-liberal, but rather they attempted to realign what liberalism meant.

The socio-liberalism of the Danish Peoples Party revolved around the authoritative nature of Islam. Their liberalism was almost exclusively in opposition to Muslim migrants, who were seen not to share liberal attitudes in northern Europe regarding gender and sexual preferences. This relatively recent commitment to liberalism is thus fuelled by their antiIslam agenda. 
This repositioning of the populist message, in protection of the West's liberalism against authoritarian Islamism, was made by several nativist populists in the third wave. Even some of those who had started out striking a highly masculine tone, turned to claim that they were now the true protector of women's rights. They would pick and choose which aspects of liberalism they would follow, and most often those useful in opposing Islam. In other words, it was an opportunistic move. More generally this was a move from authoritarianism to socio-liberalism aimed against Muslims.

In recent years nativist populists have not necessarily always been rightwing on the socio-economic axis. Many of them have indeed found success in occupying the traditional space of social democratic parties. Even the National Rally (formerly the National Front) in France has travelled from the right end of the socio-economic spectrum towards the centre, and on some issues even all the way over to the left of it.

The Sweden Democrats were never right-wing on the socio-economic spectrum. Instead, they presented a nostalgic backward-looking vision and incorporated the previous ambition of the Social Democrats of transforming Sweden into a genuine People's Home. However, the SD presented immigration as a threat to the People's Home and to the promise of universal welfare for the native population.

Rather than primarily referring to the social-economic situation of the ordinary people the emphasis of nativist populist has thus moved over to a socio-cultural notion of our people.

As I have discussed on these pages, the rise of nativist populism has had various effects. One is a greater volatility between elections in many Western states and the increased fragmentation of party systems in many countries. Governments now change much more frequently than before. The centrifugal nature of this trend has led to a transformation in European party politics, where centre parties are largely losing to the periphery at both ends.

One side effect of this activity has been an ongoing call for renewal in politics, generally dismissing political experience and instead bringing an increased appetite for inexperienced newcomers. When insisting that the professionalization of politics had turned governance into a trade that ordinary folks were in effect barred from, populists attempt to discredit mainstream professional politicians. This drive for the re-amateurization of politics has brought the political novice to prominence, and dismissed from duty many experienced and skilful politicians. This became evident 
during the Coronavirus Crisis of 2020. Authorities in several countries under control of populists leaders initially responded by dismissing warnings made by specialists, later finding themselves inept in dealing with the complexity of the calamity.

In undermining traditional politics and in vilifying the establishment the Neo-Nationalist era has indeed brought about the demise of many traditional political parties. This has given way to the populists establishing new party constructs, which, usually stripped of traditional party structures, were turned into vehicles of their leaders to wage a challenge against the establishment.

Populism has often been dismissed by the mainstream as being a pathology, some sort of delusion and deviation from normal politics. That has always been misleading. And after populist politics has infiltrated the mainstream - to the extent that here has been documented - it is apparent that the feeling driving these surges cannot simply be dismissed or marginalized as paranoid and/or delusional. Populism should thus not necessarily always be viewed as being derogative or negative.

Although populism can in many instances be viewed as perilous-at times leading to violence and the erosion of democracy, as here has been established-it can also in some situations be seen as a sensible strategy of the deprived and powerless who are faced with a socio-economic order that is skewed against them.

Over the past decades public authority has clearly been shifting to nongovernmental actors, such as specialists, media and financial elites. In many Western countries special interests have become increasingly stronger. It is therefore not an illegitimate claim, upheld by many populist leaders, that politics has become increasingly alien to the common people. In that regard, populism can thus be a practical tool to delegitimize established authority and power relations for the purpose of winning back lost authority from an overtly powerful elite.

Understanding a longing for 'sticking it' to the establishment elite is key to comprehending the rise of nativist populism. This feeling has indeed been brewing among many people who feel left behind. It is, though, equally important to keep in mind, that there are several forces at play here. No single factor can be found driving the populist surge. Economic anxiety is surely one. But cultural backlash is another. To get the full picture it is not sufficient only to look at those left behind in the fastmoving global economy. Neither is it enough to view this trend as solely a 
nativist cultural backlash against immigration. The two are here intertwined, and they are also entangled with other aspects as well.

Donald Trump proved to be especially skilful in playing on divides in America, on the increasing economic anxiety and fears of cultural replacement. While spurring horror among most of the prosperous educated economic elites on the coasts, many people in the more deprived inland areas were glad to see somebody 'sticking it' to the ruling class.

Many people in these inland areas felt left out in the fast-moving economy of the twenty-first century. On the coasts some people would refer to the Mid-West and more deprived areas in demeaning ways, calling them the Rustbelt or the flyover states. In the more deprived areas that had lost masses of manufacturing jobs, many felt that that trade deals made by Washington benefitted only externals - either foreigners abroad or increasing number of Latino workers flocking over to the US. Keep in mind that absolute level of the economy is not the only driving factor here-no less significant is the sense of one's own situation in society compared to others.

This growing gap has for a long while been somewhat overlooked by the liberal cosmopolitan elite in America. Trump, however, told them what they wanted to hear, and even though he himself was a flamboyant millionaire from Manhattan, deprived whites proved to be happy using him as a kind of a wrecking ball on the Washington establishment.

As already explored, Trump did not just emerge from out of the blue. In fact, as I have discussed over the three previous chapters, the Republican Party had for decades been flirting with notions that Trump was able to play on, of pitting the virtuous people against parasite 'others'.

As I have already examined, the nativist populism of contemporary times has travelled in waves elevated by crises-similar to the fascism of the interwar years, which was largely born out of the Great Depression of 1929. Parties of this kind have ascended to power when successfully playing on polarizations within their respective societies, most often when aided by establishment collaborators. Although history holds many examples of polarization leading to a populist rise, it also teaches-as I discussed above - that when liberal democratic forces unite across traditional political dividing lines, they can commonly curb the surge of illiberal actors.

By the time of the Coronavirus Crisis of 2020 we had, witnessed a new counter-wave emerging, a kind of anti-populist pushback against the nativists and their populist gale. However, with the new crisis nationalist sentiments were mounting once again. Although Covid-19 was a global outbreak, it still prompted a highly nationalist response in many places. In 
Hungary, Viktor Orbán and the Fidesz government went for a quick power grab, almost completing the transformation to authoritarianism. In Brazil, Jair Bolsonaro scorned scientific warnings around the decease. In America, Donald Trump started out dismissing most concerns raised by specialists, even those coming from within his own administration. Numerous examples like these existed of populists in power undermining proper and professional administration when dealing with the crisis. Erratic decisions and a lack of coherent and coordinated policymaking served to deepen the crisis.

The Coronavirus Crisis also illuminated the importance of science and professional governance. The crisis clearly revealed an ongoing conflict between nativist populist politics on the one hand and governance based on established knowledge on the other. With conspiracy theories and misinformation blazing, nationalist populism was once again on the rise. It however remains to be seen whether the Coronavirus Crisis will amount to the rise of a fourth wave of Neo-Nationalism. 